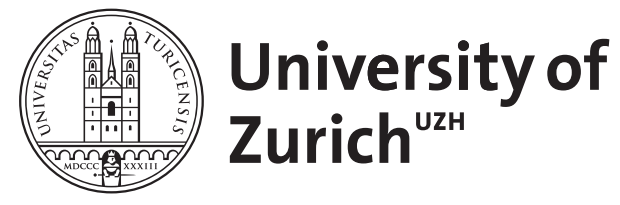
Archive

University of Zurich

University Library

Strickhofstrasse 39

CH-8057 Zurich

www.zora.uzh.ch

Year: 2011

Gold standard. Reply: editorial. J Pediatr Urol 2010;6:329.

González, R

DOI: https://doi.org/10.1016/j.jpurol.2010.09.019

Posted at the Zurich Open Repository and Archive, University of Zurich

ZORA URL: https://doi.org/10.5167/uzh-58199

Journal Article

Accepted Version

Originally published at:

González, R (2011). Gold standard. Reply: editorial. J Pediatr Urol 2010;6:329. Journal of Pediatric Urology, 7(1):98; discussion 99.

DOI: https://doi.org/10.1016/j.jpurol.2010.09.019 
Letter to the Editor

\title{
Gold standard. Reply: Editorial. J Pediatr Urol 2010;6:329
}

\author{
Ricardo Gonzalez \\ Universität Kinderspital Zürich \& Kinderkrankenhaus auf de Bult Hannover, Switzerland
}

The term gold standard can have a profound effect on the choice of procedures by surgeons, particularly the young and inexperienced, and even more so when it is employed by the editors of an important journal. With the current price of gold, one should exercise caution when using the term.

Gold, the 79th element in the periodic table with the chemical symbol Au, has not changed over millennia; however, the so-called surgical gold standards change over time with the development of new techniques, better understanding of the disease processes, and results being published from centers other than the place of origin of the procedure.

That Snodgrass, Bush and Cost (J Pediatr Urol 2010; 6:408e13) report a 4\% complication rate with the tabularized incised plate (TIP) hypospadias repair deserves congratulations, but hardly merits calling theirprocedure 'the gold standard for other surgeons to compare their results with'. One should consider that the mean follow up was only 8.2 months, only $65 \%$ of the patients had urinary flows and $23 \%$ had no follow up, and in $17 \%$ the plate was not incised. When the plate is not incised the procedure is no longer a TIP but a variation of the ThierscheDuplay popularized, among others, by Kass et al. [1,2].

Others groups have reported that between $25 \%$ and $40 \%$ of patients do not achieve a bell-shaped flow curve after TIP [3e5]. That the dorsal incision causes a permanent increase in the caliber of the urethra when the plate is narrow has been questioned [6]. This should be a cause of concern for the future of these children, who generally undergo the procedure for cosmetic reasons and may end up with a distal urethral stricture. The repair of strictures after TIP is not always easy. A ventral meatoplasty will often result in a meatus in the same position as before the repair. Often the best solution is a dorsal inlay of buccal mucosa or penile skin, according to the availability of skin. This is a rather major undertaking, and some will incise the plate and place a graft at the initial setting [7].

My personal preference for the last 15 years has been to do a simple tubularization when the plate is wide and the glans groove deep, and to augment the plate by means of a preputial onlay flap or a meatal based flap when narrow.

In short, the 2010 gold standard for distal hypospadias repair has not yet been determined. Respectfully submitted.

1. Kass EJ, Chung AK. Glanuloplasty and insitu tubularization of the urethral plate: long term followup. J Urol 2000;164(3 Pt. 2): 991e3.

2. van Horn AC, Kass EJ. Glanuloplasty and in situ tubularization of the urethral plate: a simple reliable technique for the majority of boys with hypospadias. J Urol 1995;154:1505e7.

3. Andersson M, Doroszkiewicz M, Arfwidsson C, Abrahamsson K, Holmdahl G. Hypospadias repair with tubularized incised plate: does the obstructive flow pattern resolve spontaneously? J Pediatr Urol; 2010, July 12 [Epub ahead of print].

4. Scarpa MG, Castagnetti M, Berrettini A, Rigamonti W, Muis L. Urinary function after Snodgrass repair: comparison with the Mathieu procedure. Pediatr Surg Int 2010;26:519e22.

5. Tuygun C, Bakirtas H, Gucuk A, Cakici H, Imamoglu A. Uroflow findings in older boys with tubularized-incised plate urethroplasty. Urol Int 2009;82:71e6.

6. Holland AJ, Smith GH. Effect of plate depth and width on tubularized incised plate urethroplasty. J Urol 2000;164: 489e91.

7. Ferro F, Vallasciani S, Borsellino A, Atzori P, Martini L. Snodgrass urethroplasty: grafting the incised urethral 